$(9,000 \mathrm{rpm})$ と $1.5 \mathrm{~mm}(3,000 \mathrm{rpm})$ では, $0.2 \mathrm{sec}$ で約 30 $\% の X$ 線管電流の増加が得られる。

(2) X線管焦点 $1 \mathrm{~mm}, 1.5 \mathrm{~mm}, 2 \mathrm{~mm}$ をおのおの FTD $55 \mathrm{~cm}$ にて, 問題の $1.2 \mathrm{~mm}$ を FTD $45 \mathrm{~cm}$ にて Response で求め，てれより $1.2 \mathrm{~mm}$ 焦点は，FTD $55 \mathrm{~cm}$ に拉ける $1.4 \mathrm{~mm}$ の仮想焦点とみなすととが出来る.

（3）透視条件：FTD $55 \mathrm{~cm}$ では，被写体厚 $18 \mathrm{~cm}$ 乙 れに対しFTD $45 \mathrm{~cm}$ では, $21 \mathrm{~cm}$ まで同一輝度で観察 できる.

(4) 撮影条件では, 同一濃度を得るのに18cmで $4 \mathrm{kVp}$, $22 \mathrm{~cm}$ で $8 \mathrm{kVp}$ の差がある。

撮影条件の低下は，Grid Ratio む小さくでき同時に テレビ画像も広範囲の明るさを得られる，以上の如く， 標準規格に対し多くの点に有意であった。

\section{4. 間接フィルムの自動現像機処理について}

神奈川県立成人病センタ一 放射線科 梅津 幹夫・酒井 聡子. ○斎藤美紀雄

(目的)

胃部間接撮影では，自動現像機処理方法が，各施設で 適時行なわれているのが現状である。今回われわれは自 動現像機に対する間接フィルムの最適処理方法について 比較検討した.

(方法)

3 社のフィルム, 4 種類を光露光にて濃度階段を作り, 自現機 5 台にて温度を変え 4 種のフィルムを同時に現像 し，そのフィルムの特性曲線汃ら ASA 規格より比感度, 平均階調を求めた。

(結果)

富士 $\mathrm{KX} フ ィ ル ム の$ 感度と平均階調は，ある限度まで 現像温度が上るにつれ高く, それ以上あがると逆になる ことがわかった，33度では各自現機ともカブリが低く， 感度, 平均階調が高く最適であった。富士 FXについて あ $\mathrm{KX}$ と同様であった. コダックの間接フィルムは, $\mathrm{KX}, \mathrm{FX}$ に比較して, 各自現機の現像進行性に差があっ た. カブリは他フィルムに対して高かった。 サクラ GH は, カブリ, 感度, 平均階調とも各温度にて他フィルム に同様であった．次に各自現機別に各フィルムについて 比較した。 コダック M4 では,カブリは, $\mathrm{KX}, \mathrm{FX}, \mathrm{GH}$,

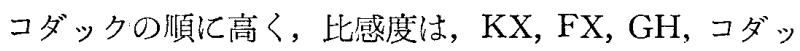

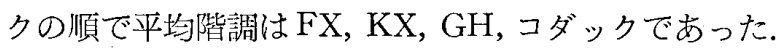
$\mathrm{FX}, \mathrm{KX}, \mathrm{GH}$ は33〜35度位の温度では, カブリが増さ ず, 感度, 平均階調を上る事がわかった。他の自現機も ほぼ同様であった。 また神奈川県内で，自動現像処理を 行なっている4施設の处理状態についても検討した.
(結果)

1）各フィルム共に液温 33 度士 2 度現像が最適であっ た.

2）5台の各自動現像機共にフィルムに対するる特性は 殆んど変らなかった。

3） KX, FXフィルムが各自動現像機とも共通して良 い結果を示した。

\section{5. 喉頭多層断層の検討}

神奈川県立成人病センター 放射線科

梅津 幹夫・酒少聡子・田浅川 芳久

今回は撮影体位撮影方法, 振り角度等について検討し たので報告する。装置はシーメンス社製ユニバーサルプ ラニの多層断層を使用した。

(〕)体位の検討 : 喉頭断層撮影を行なう場合, 喉頭腔が フィルム面に刘し平行となり，喉頭腔が開口する必要 がある. そのため仰卧位における喉頭側面撮影より検 討した結果，腹臥位でフィルム面に対し，OM lineが $60^{\circ}$ が最良であった。 喉頭断層の写真は左存対称性を 診断的価值としている，仰臥位において頭部左右の固 定, アゴの固定, 発泡スチロールによる頭座の固定, 以上を同時に実施し，体位の固定を行なった．計測に つては皮膚最高点より喉頭腔上端までの距離は成人 男子では平均 $1.7 \mathrm{~cm}$ ，女子について $1.3 \mathrm{~cm}$ であった。 喉頭腔の直径は男女とも大差なく平均して $2.1 \mathrm{~cm} て ゙$ あった．との值を参考にして切断面は決定できる.

(9)振り角度および管球移動方向: $40^{\circ}$ 薄層, $15^{\circ}$ 厚層 について基礎実験，臨床奏験を行なったが核像の大き さ，鮮鋭度の問題で $40^{\circ}$ 溥首の方が有利であった。一 方移動方向については体軸に対し, 横振り縌振りにつ いて実験したが，横振りでは頸椎の流れ像が障害とな り彭断的佂值は少る。文た体軸方向に管球を振らす場 合には頭 $\rightarrow$ 足, 足 $\rightarrow$ 頭の 2 つ方法功考えられる. 結 果加らは，顎の㜔害院影等の関係で足 $\rightarrow$ 頭の方が有利 だった，発声については次に示す一般的 3 回の発声方 法で行なう。

quiet inspiration (IN)

Low-piched Lettere (E)

Valsalva Maneuver (V).

撮影方法については $40^{\circ}$ 溥層に执いて $5 \mathrm{~mm}$ 間隔で 4 枚撮している. 条件は比較的低電圧撮影を行なう事 が必要である。

(9) 結論：今回は撮影体位として OM lineがフィルム 面に対して $60^{\circ}$ 仰卧位による固定を行ない，足方より 体軸方向の多㬝断層撮影が有利であった。 